\title{
Transposing NOISE and Voice
}

\author{
Rosemarie Buikema and Nina Lykke
}

I call the living

I mourn the dead

I break the lightning

A transposition indicates an intertextual, cross-boundary, or transversal transfer, in the sense of a leap from onecode, field or axis into another, not merely in the quantitative mode of plural multiplication but rather in the qualitative sense of complex multiplicities. (Braidotti 2006g, p. 5)

\section{Abstract}

This chapter connects Rosi Braidotti's work as a philosopher to her voluntary occupation as bell-ringer and member of the Utrecht Carillon Guild, arguing that Braidotti through the latter practices the former. Braidotti's voice has been heard internationally for quite some time and is still very audible as the inspiration of Pussy Riot testifies. But Braidotti also connects to past feminist voices such as the Dutch Anna Maria van Schurman and to the future as her theories of posthumanism testify. The chapter narrates the political, artistic, and philosophical impact of Braidotti on local and global feminist activism.

\section{Keywords}

Pussy Riot, Anna Maria van Schurman, bell-ringing, feminist activism, posthumanism, NOISE

The staccato motto of this contribution to the contemplation of the subject(s) of Rosi Braidotti might be recognized by its main addressee only. It is borrowed from a minoritarian 
and, thus, the most fascinating aspect of her life and work: Braidotti's identity as a carillonneuse of the Dom Tower in Utrecht, The Netherlands. Like most of the noted thinkers, artists, and politicians of our time, after decades of inventing new theories and communityconstituting infrastructures, Braidotti manages to perform the ultimate actualization of her visions, thoughts, and concepts through a seemingly simple material praxis. In her case, the praxis is this: ring the bell. Few people might know that Braidotti is a certified bell-ringer and member of the Utrecht Carillon Guild. How does one transpose one's visionary and revolutionary theories more effectively than by literally ringing a bell and inscribing oneself in the age-old honorable practice of bell-ringers? Isn't the main feature of a bell that it makes noise?

Invented to attract a large group of people, every bell indeed distinguishes itself from other bells by the unique intensity and quality of its sound. In addition, every bell carries its own inscription, the urinscription being: "I call the living, I mourn the dead, I break the lightning." In order to be effective, the bell, of course, needs a bell-ringer to make it ring. A daunting thought when this bell-ringer is Rosi Braidotti transposing the force of her thoughts to the production and control of the duration of noise. Finally, bells have a geopolitical history of metamorphoses or substantial transposition: In times of war, bells transform to canons; in times of peace, those canons metamorphose back to bells.

\section{I call the living}

Braidotti is part of a community of power-feminists in Europe. Her symbolic bell tolls across a wide and expansive landscape of contemporary intellectual and artistic practices. Peculiar to her feminist enterprise is the fact that it is characterized by a genuine belief in the potential power of the arts to provide knowledge and to provoke change. From Laurie Anderson and Banksy to Virginia Woolf, they all inhabit Braidotti's intellectual and political engineerings. The cross-fertilization between feminist art and feminist philosophy thus marks both the urgency and valorization of Braidotti's work.

A powerful example of what this might lead to in the world is the recent Pussy Riot case. Explicitly inspired by feminist philosophies, most notably the work of Braidotti, this female punk band, their faces covered by colored balaclavas, managed to put their feminist and anticapitalist agenda not only on the national stage, but also under a giant international spotlight. They were strategically liberated after 2 years of imprisonment as a device to polish Putin's reputation in the run up to the 2014 Olympic Games in Sochi. Once released, they immediately returned to ringing the bell, calling for justice and human rights in contemporary Russia. When they "riot," they make noise, singing and shouting texts such as "Mother of God, become a feminist”, forcing society to deal with their critical and subversive voices. Their acts are reminders that little progress has ever come to any society without the participation of those who live on its fringes; those who occupy the spaces far beyond patriarchal, religious, and governmental institutions, and those who dare to ring their bells. As a true student of 
Braidotti's work, Pussy Riot shows that, at least in the context of contemporary Russia, popular culture and the arts still matter. The documentary portraying their legendary (and largely for show) court case-after which they were sentenced to the 2 years of incarceration — starts with a quote of $\mathrm{Br}(\mathrm{echt})$ : “Art is not a mirror to reflect the world, but a hammer with which to shape it," which could as well have been a quote of $\mathrm{Br}$ (aidotti).

We are not quite sure if this is what neoliberalism calls the valorization of knowledge, but if European feminism manages to activate the activists and irritate, not to say, alarm Putin, it must be doing something right. In any event, Braidotti and Pussy Riot shook hands in The Netherlands soon after the release of Nadesezhda (Nadya) Tolokonnikova and Maria (Masha) Alyokhina: we will hear more of this explosive cocktail of Eastern protest and Western critical thought.

\section{I mourn the dead}

When thinking about noise, bells, and Rosi Braidotti, we inevitably also need to talk about one of the most memorable co-citizens of the city of Utrecht: Anna Maria van Schurman (1607-78). Van Schurman's and Braidotti's names and vicissitudes are interconnected for too many reasons to entirely list here, but they all lead again to NOISE and a bell in the end.

To start from the here and now, Braidotti's Utrecht University Centre for the Humanities is located in the same street, directly behind the Dom Church in Utrecht, where Anna Maria van Schurman spent her youth as a prodigy. Here Van Schurman developed herself into a polyglot speaking and reading an incredible collection of languages by the age of eleven. In 1636, she managed to become the first female student of the University of Utrecht attending classes behind a curtain so as not to disturb the male students (balaclavas were not in vogue yet). Braidotti retold Van Schurman's story for years as an exemplary case of both female agency and Foucauldian power as potentia to the students of "Eros and Pathos," a typical Utrecht gender studies class taught to underline the interdependency of feminist knowledge and feminist artistic research and the importance of feminist knowledge as derived from women's artistic practices. Here, art was taught as philosophy. Showing Judy Chicago's The Dinner Party, the monumental installation that celebrates thirty-nine inspirational women from history, inevitably leads to feminist histories, theories, and historiographies. Each woman in this artifact is represented by a ceramic plate decorated with vulva and flower forms to remind us that it is only this sexual difference that separates one tradition or canon from the other.

In the case of Van Schurman, Chicago embroidered one of her famous quotes across the top of the runner for her place setting at the dinner table and this provided the entry point that in class led to discussion of its encounter with sexual difference-thinking:

Woman has the same erect countenance as man, the same ideals, the same love of beauty, honor and truth, the same wish for self-development, and yet she is to be imprisoned in

an empty soul of which the very windows are shuttered. ${ }^{1}$ 
Van Schurman's plate was, of course, discussed next to those of other heroines, such as nomad avant la lettre and Braidotti's favorite author Virginia Woolf: "I am rooted but I flow” (Woolf 2004, p. 66), from the original 1931 novel The Waves. Teaching in the time before the age of PowerPoint and the Internet (we are barely in the 1990s here) also meant that using a plethora of images while making a theoretical point was not yet that common. So not only the message, but also the form, produced a revolutionary educational praxis. Aesthetically served dinner parties became signs of feminist resistance as opposed to iterations of heterosexual codes of domesticity.

The format of "Eros and Pathos," that is, taking women's art as the mechanism for knowledge production focused upon women's subjectivity and sexuality while conversely examining the knowledge students acquired through reading academic texts by their artistic performances, is a format Braidotti transposed throughout the enterprise of curriculum building for local, national, and international gender studies. The enduring impact of the European Summer School NOISE experience ${ }^{2}$ is evident to this day, especially for its Friday afternoon sessions. After 1 or 2 weeks of intellectual labor, students present their appropriation of the knowledge offered by the NOISE curriculum of that particular edition. Over the past 23 years, NOISE students have never disappointed the international team of gender studies instructors in those final sessions when they use their bodies to demonstrate the work of their minds, and thus concludes a week or two of creative thinking. Through this creative endeavor, most of the NOISE students then transform into undivided Riot Grrrls.

However, Van Schurman meant more for the empire of UU gender studies than simply an exemplary heroine. She additionally lent her name to a consortium of UU gender scholars under the direction of Rosi Braidotti. The Anna Maria van Schurman centre at UU turned out to be the predecessor of the Netherlands Research School of Women's Studies (NOV, now NOG). Braidotti's visionary intuition never limited her actions to local terrains, so gender studies UU also became gender studies NL soon. However, not co-incidentally, Anna Maria van Schurman was ultimately to traverse Rosi's path again as sister, prodigy, feminist, and Utrecht citizen when, in 2010, the University of Utrecht and the Utrecht Carillon Guild jointly honored Van Schurman's intellectual legacy by casting a real bronze bell to be hung in the tower of the UU academy building. The inscription was a quote from one of Van Schurman's letters to a friend after having left Utrecht: "Oh Utrecht, dearest city, how could I ever forget you." The next section in this meandering story about the memorable dead thus runs that Braidotti, being the only UU professor in the guild, was one of the first to not only symbolically but also literally ring this bell ... !

\section{I break the lightning}

And yet, at one of the first large European Feminist Research Conferences, organized in Brussels, Belgium, in 1989 by the feminist journal Les Cahiers du GRIF, Braidotti entered the 
scene with the words, “All we have in common sisters, are our differences!” The paradoxes and dilemmas that poststructuralist, postcolonial, and queer feminists were already forcefully putting on the agenda, even back then, were at once both elegantly captured and affirmatively transgressed. Braidotti's message, already then and there, was this: Intersecting differences along the lines of race, ethnicity, class, and sexuality are totally subverting standpoint-feminist ideas of universal sisterhood. But still, in the midst of all the diversity and difference at stake here, feminist politics and thinking have the power to interpolate a passionate "we" to mobilize collective political action.

Since then numerous, resonant international keynote addresses have been delivered by Braidotti. The most recent one was at a conference on the posthuman, titled "Negotiating the Humanities: Humanities Towards a New Agenda,” which took place in Aarhus, Denmark, in November 2013, about 25 years after the one in Brussels. Here Braidotti articulated a fierce and humorous critique of the laments of the privileged white hu/man subject of the traditional Humanities. The audience took visible pleasure in listening to her passionate arguments for a sustainable nomadic ethics embedded in the affective dynamics and generative forces of zoe. Braidotti addressed the manner in which the present ecological crisis and the lack of political will to seriously act in sustainable ways may be pushing humanity toward extinction. Prompted by a Spinoza-Deleuze-inspired desire for an affirmative approach, Braidotti suggested that the impasse could perhaps be transgressed and, in the process, the millions of different vested human interests that prevent us from actually opting for more sustainable ways of living, could perhaps be bypassed. A shared recognition of humanities' endangeredness, going hand in hand with a zoe-generated desire and passion for staying alive, might urge us to act differently. A new and more sustainable, posthuman and postanthropocentric version of the Humanities could also, according to Braidotti, grow from this recognition. Here sexual difference politics were applied to the sustainability debates understood as another affirmative politics, based on the paradoxical position of a "we" that definitely is not one. There was the old quote revitalized in a new context: "All we have in common, fellow human subjects, is that we are inhabiting the subjectivity of an endangered species!”

Braidotti's importance for the unfolding of feminist materialist theories on the posthuman urged Linköping University, Sweden, to honor Braidotti in 2013 by awarding her an honorary doctorate, a gesture that stressed her feminist and posthuman theoretical connections with the Linköping gender studies unit. The still-to-be-written next step in this unfolding narrative concerning the local, national, and global impact of the feminist posthuman Braidotti's noise and voice will, inevitably, be the casting of a Braidotti bell on top of the European gender studies enterprise, the inscription obviously being: "All we have in common sisters, are our differences!”

\section{Notes}

\section{See:}


http://www.brooklynmuseum.org/eascfa/dinner_party/place_settings/anna_van_schurman. [accessed 8 March 2014].

2 See: http://www.graduategenderstudies.nl/education/noi o se-summer-school/ [accessed 8 March 2014].

\section{Reference}

Woolf, V. (2004), The Waves, London: Vintage, (1931). 